\title{
Total alkaline phosphatase activity in water of Rusalka lake in the city of Szczecin
}

\author{
Piotr Daniszewski \\ Department of Invertebrate Zoology and Limnology, Faculty of Biology, University of Szczecin, \\ 13 Waska Street, 71-415 Szczecin, Poland \\ E-mail address: daniszewski73@gmail.com
}

\begin{abstract}
The progress of civilizations causes changes in the water catchment areas lakes. aquatic waters are order - phosphorus and nitrogen compounds. Level of activity alkaline phosphatase (APA) has an important impact on the chemical and biological processes taking place in the aquatic environment. APA belongs to a group of indicators, who tells us about the extent limitations to development of biomass in the tank water. Water of Rusalka lake were the subjects of 2008-2012 (July - September). Total alkaline phosphatase activity was determined seven times a year in these environments. A study of seasonal fluctuations showed that a maximum total alkaline phosphatase activity, both in the water and in the bottom sediment, occurred in spring (May) and summer (July, August).
\end{abstract}

Keywords: total alkaline phosphatase activity; water; Rusalka lake

\section{INTRODUCTION}

Phosphorous plays a key role in biological production and thereby in the eutrophication of the water environment [4-7,11,21-23]. One of the important processes impacting on the level of available mineral phosphorous is enzymatic hydrolysis of organic bonds of this element $[11,19,22,23]$.

A majority of previous studies shows that alkaline phosphatase is chiefly responsible for the rate of organic phosphorous mineralization, both in the pelagic zone and in the bottom sediment of water bodies with $\mathrm{pH}>7$ [1-9,11,13-15,20,23]. However, some authors report, e.g. Yiyong [15], that abiotic factors can also play a part in the process. Jones [15] suggests that the level of phosphatase activity in the water is linked to the degree of lake trophicity.

Whereas phosphatase activity in bottom sediment, according to Kobari and Taga [16], can indicate their enzymatic potential.

The assumption for this cycle of study was also to demonstrate the usefulness of the applied enzymatic test as a biological indicator of the degree of lake trophicity and possibly of progressing eutrophication of the analyzed water bodies. 


\section{EXPERIMENTAL}

Szczecin is situated in North-Western Poland, in the western part of West Pomeranian Voivodeship in the Polish-German border [24].

Rusalka Lake, otherwise called the sea Eye, is located in Szczecin Kasprowicz Park in Niebuszewo district. This is the reservoir formed by the medieval Mill River House Osówka [24]. Lake morphometric data: Length - $670 \mathrm{~m}$, width - $70 \mathrm{~m}$, the height of the mirror - $16 \mathrm{~m}$ above sea level, type of lake: prohibitive [24].

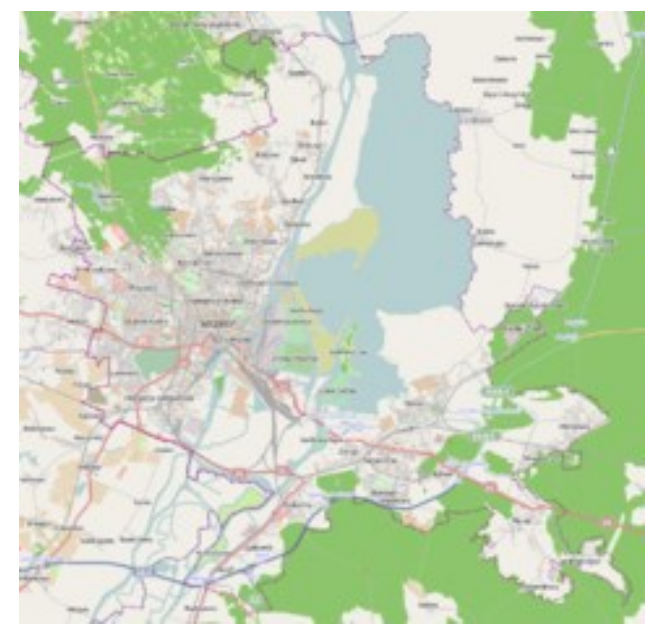

Map 1. Location of the measuring point in Rusalka lake in Szczecin $53^{\circ} 26^{\prime} 44^{\prime \prime} \mathrm{N} 14^{\circ} 32^{\prime} 05^{\prime \prime} \mathrm{E}$

Samples of littoral and sublittoral water were taken with a Ruttner sampler with a capacity of $2 \mathrm{dm}^{3}$. Water and sediments were stored for 24 hours at $4{ }^{\circ} \mathrm{C}$.

After that time total alkaline phosphatase activity in water was determined with the use of Jones's method [15], which involves detecting coloured p-nitrophenol formed from $\mathrm{p}$ nitrophenol phosphate dissolved in a buffered solution ( $0.1 \mathrm{M}$ Tris- $\mathrm{HCl}$ of $\mathrm{pH} 8.5)$.

Activity of that enzyme in bottom sediments was established in accordance with Tabatabai and Bremmer [23], using the aforementioned buffer solution. The study was conducted during 2008-2012.

The analyses were carried out 7 times a year (April, May, June, July, August, September and October), in three repetitions.

\section{RESULTS AND DISCUSSION}

Results of the General activity of the alkaline phosphatase in the Deep waters of the Lake in Rusalka are presented in Tables 1 to 5. 
Table 1. The total alkaline phosphatase activity in water $\left(\mathrm{nmol} \mathrm{PO} \mathrm{PO}_{4} \cdot \mathrm{dm}^{-3} \cdot \mathrm{h}^{-1}\right)$ in 2008 .

\begin{tabular}{|c|c|c|c|}
\hline No & Analysis terming & Litoral & Sublitoral \\
\hline \multicolumn{2}{|c|}{$\mathbf{2 0 0 8}$} & $\mathbf{1} \mathbf{~ m}$ & $\mathbf{4} \mathbf{~ m}$ \\
\hline 1. & April & 378,2 & 282,9 \\
\hline 2. & May & 432,9 & 429,5 \\
\hline 3. & June & 492,2 & 452,8 \\
\hline 4. & July & 531,4 & 562,5 \\
\hline 5. & August & 492,6 & 476,6 \\
\hline 6. & September & 384,7 & 352,7 \\
\hline 7. & November & $\mathbf{4 8 5 , 9}$ & $\mathbf{4 3 4 , 1}$ \\
\hline
\end{tabular}

Table 2. The total alkaline phosphatase activity in water $\left(\mathrm{nmol} \mathrm{PO} \cdot \mathrm{dm}^{-3} \cdot \mathrm{h}^{-1}\right)$ in 2009 .

\begin{tabular}{|c|c|c|c|}
\hline No & Analysis terming & Litoral & Sublitoral \\
\hline \multicolumn{2}{|c|}{$\mathbf{2 0 0 9}$} & $\mathbf{1} \mathbf{~ m}$ & $\mathbf{4} \mathbf{~ m}$ \\
\hline 1. & April & 354,8 & 264,9 \\
\hline 2. & May & 428,1 & 387,3 \\
\hline 3. & June & 492,9 & 496,7 \\
\hline 4. & July & 682,5 & 597,3 \\
\hline 5. & August & 582,3 & 463,8 \\
\hline 6. & September & 393,6 & 482,6 \\
\hline 7. & November & $\mathbf{4 8 7 , 1}$ & $\mathbf{4 3 6 , 0}$ \\
\hline
\end{tabular}


Table 3. The total alkaline phosphatase activity in water $\left(\right.$ nmol $\left.\mathrm{PO}_{4} \cdot \mathrm{dm}^{-3} \cdot \mathrm{h}^{-1}\right)$ in 2010 .

\begin{tabular}{|c|c|c|c|}
\hline No & Analysis terming & Litoral & Sublitoral \\
\hline \multicolumn{2}{|c|}{$\mathbf{2 0 1 0}$} & $\mathbf{1 ~} \mathbf{~}$ & $\mathbf{4 ~ m}$ \\
\hline 1. & April & 387,4 & 293,8 \\
\hline 2. & May & 489,1 & 387,3 \\
\hline 3. & June & 566,9 & 462,6 \\
\hline 4. & July & 692,5 & 596,2 \\
\hline 5. & August & 584,3 & 481,9 \\
\hline 6. & September & 563,4 & 523,7 \\
\hline 7. & November & $\mathbf{5 3 4 , 9}$ & $\mathbf{4 4 6 , 9}$ \\
\hline
\end{tabular}

Table 4. The total alkaline phosphatase activity in water $\left(\mathrm{nmol} \mathrm{PO}_{4} \cdot \mathrm{dm}^{-3} \cdot \mathrm{h}^{-1}\right)$ in 2011 .

\begin{tabular}{|c|c|c|c|}
\hline No & Analysis terming & Litoral & Sublitoral \\
\hline \multicolumn{2}{|c|}{$\mathbf{2 0 1 1}$} & $\mathbf{1} \mathbf{~ m}$ & $\mathbf{4} \mathbf{~}$ \\
\hline 1. & April & 409,4 & 363,7 \\
\hline 2. & May & 472,3 & 452,2 \\
\hline 3. & June & 534,8 & 495,3 \\
\hline 4. & July & 565,2 & 582,5 \\
\hline 5. & August & 489,2 & 512,8 \\
\hline 6. & September & 428,6 & 379,6 \\
\hline 7. & November & $\mathbf{5 1 1 , 6}$ & $\mathbf{4 6 4 , 0}$ \\
\hline \multicolumn{2}{|r|}{} \\
\hline
\end{tabular}


Table 5. The total alkaline phosphatase activity in water $\left(\mathrm{nmol} \mathrm{PO}_{4} \cdot \mathrm{dm}^{-3} \cdot \mathrm{h}^{-1}\right)$ in 2012 .

\begin{tabular}{|c|c|c|c|}
\hline No & Analysis terming & Litoral & Sublitoral \\
\hline \multicolumn{2}{|c|}{$\mathbf{2 0 1 2}$} & $\mathbf{1} \mathbf{~ m}$ & $\mathbf{4} \mathbf{~}$ \\
\hline 1. & April & 391,4 & 357,4 \\
\hline 2. & May & 498,5 & 424,7 \\
\hline 3. & June & 528,9 & 487,3 \\
\hline 4. & July & 559,7 & 592,8 \\
\hline 5. & August & 491,7 & 493,5 \\
\hline 6. & September & 382,9 & 324,6 \\
\hline 7. & November & $\mathbf{5 0 4 , 5}$ & $\mathbf{4 4 1 , 4}$ \\
\hline
\end{tabular}

The results presented in in Tables 1 to 5 demonstrate that total alkaline phosphatase activity in the waters of Rusalka lake over the five-year period of study oscillated between 264.9 to $692.5 \mathrm{nmol} \mathrm{PO}_{4} \cdot \mathrm{dm}^{-3} \cdot \mathrm{h}^{-1}$. The oscillation range in both zones of the analyzed water body was similar. In the littoral it ranged from 354.8 to $692.5 \mathrm{nmol} \mathrm{PO}_{4} \cdot \mathrm{dm}^{-3} \cdot \mathrm{h}^{-1}$, and in sublittoral from 264.9 to $597.3 \mathrm{nmol} \mathrm{PO}_{4} \cdot \mathrm{dm}^{-3} \cdot \mathrm{h}^{-1}$.

Comparing 5-year average values of the analyzed activity in the waters of selected Rusalka lake zones, it was established that it was lower in the littoral than in the sublittoral.

Total alkaline phosphatase activity in the water and bottom sediments of the analyzed water body was subject to seasonal oscillations. Irrespectively of the state of the environment aggregation, they typically demonstrated similar course in both analyzed zones.

Both in the water and in the bottom sediments a higher level of the activity was determined in spring (May) and in full summer period (July and August).

In the pelagic zone a maximum of total alkaline phosphatase activity occurred in July, which is consistent with the results of research the author of this paper conducted on other lakes.

What is noteworthy is the fact that higher values of the studied activity were not always accompanied by larger number of bacteria and saprophytic fungi [17, 18], which would confirm the importance of algae affecting its level.

Whereas in the bottom sediment an increase in total alkaline phosphatase activity in July and August clearly showed a link between the number of heterotrophic bacteria, which most probably results from an influx into the sediments of phytoplankton, dying after spring blooms. 


\section{CONCLUSIONS}

1. Total alkaline phosphatase activity in Rusalka lake waters was the highest in the top layer of the littoral.

2. Total alkaline phosphatase activity both in the water and in the sediment was subject to seasonal changes, and their course was of similar nature. A maximum activity was observed in both environments in the spring (May) and in the summer (July and August).

\section{References}

[1] Chróst R. J., Siuda W., Halemejko G. Z., Arch. Hydrobiol. Suppl. 70(1) (1984) 1-32.

[2] Chróst R. J., Siuda W., Limnol. Oceanogr. 31 (1986) 662-667.

[3] Daniszewski P., International Letters of Chemistry, Physics and Astronomy 1 (2012) 13-16.

[4] Daniszewski P., International Letters of Chemistry, Physics and Astronomy 2 (2012) $35-41$.

[5] Daniszewski P., International Letters of Chemistry, Physics and Astronomy 2 (2012) $42-45$.

[6] Daniszewski P., International Letters of Chemistry, Physics and Astronomy 2 (2012) 46-52.

[7] Daniszewski P., International Letters of Chemistry, Physics and Astronomy 4 (2012) 119-124.

[8] Daniszewski P., International Letters of Chemistry, Physics and Astronomy 5 (2012) 72-79.

[9] Daniszewski P., International Letters of Chemistry, Physics and Astronomy 5 (2012) 80-87.

[10] Daniszewski P., The evolution of the geographical environment and nature protection in the industrialized and urbanized areas, 44 (2012) 16-21.

[11] Furczak J., Acta Agrophysica 4(2) (2000) 291-299.

[12] Górniak A., Composition of the organic matter in lakes bottom sediments, Procc. IHSS Ins. Meeting, Barii, ed. Senesi N., Miano T.M., Elsevier Publisher, Amsterdam, 1993.

[13] Jansson M., Olssonh., Pettersson K., Hydrobiol. 170 (1988) 157-175.

[14] Jones J. G., J. Ecol. 60 (1972) 777-791.

[15] Kobari H., Taga N., Deep-Sea Res. 26A (1979) 799-808.

[16] Korniłłowicz T., Acta Mycol. 29 (1994) 23-31.

[17] Korniłłowicz T., Acta Mycol. 29 (1994) 159-168. 
[18] Misztal M., Smal H., Studia Ośr. Dok. Fizjograf. PAN, Oddział w Krakowie, 19 (1991) 193-207.

[19] Sayler G. S., Puziss M., Silver M., Appl. Environ. Microbiol. 38 (1979) 922-927.

[20] Schindler D. W., Limnol. Oceanogr. 23 (1978) 478-486.

[21] Siuda W., Pol. Arch. Hydrobiol. 31 (1984) 207-233.

[22] Tabatabai M. A., Bremner J. M., Soil Biol. Biochem. 1 (1969) 301-307.

[23] Yiyong Z. H., Hydrobiol. 335 (1996) 55-62.

[24] Janczak J., Atlas Polish Lakes (1996) 92-95. 